\title{
Böbrek Hastalıklarında Klinik Nütrisyon Yaklaşımı
}

\author{
Clinical Nutritional Approach in Kidney Diseases
}

\section{Perim F. Türker ${ }^{1}$}

Geliş tarihi/Received: 18.03.2018 • Kabul tarihi/Accepted: 30.11.2018

\section{ÖZET}

Kronik böbrek yetmezliği (KBY), glomerül filtrasyon hızının (GFH) böbrek işlevlerinde saptanabilir düzeyde değişikliklere neden olacak kadar kalııı bir şekilde azaldığı durum olarak tanımlanabilir. Son dönem böbrek yetmezliği (SDBY), endojen böbrek işlevinin geri dönüşümsüz kaybı ile karakterize ve hayatı tehdit eden üremiden korunmak için hastaya devamlı olarak diyaliz veya transplantasyon gibi renal replasman tedavilerinin uygulandığı klinik tabloyu oluşturur. SDBY insidansı ve prevalansı tüm dünyada artmaktadır. Kronik böbrek yetmezliğine eşlik eden üremik sendrom iştah kaybıyla, azalmış oral besin alımıyla sonuçlanan gastrointestinal yan etkilerle, metabolik asidoz, üremik toksisite, protein katabolizmasının başlamasıyla ilişkilidir. Malnütrisyon SDBY olan hastalarda önemli bir sorundur. Protein enerji malnütrisyonunun varlığ 1 SDBY'de artmış mortalite ve morbidite ile ilişkilidir. Malnütrisyon sık görüldüğü için, beslenme durumunun periyodik olarak değerlendirilmesi, erken tanı ve uygun tedavide diyaliz hastalarının rutin bakımının bir parçasıdır. Öncelikle tıbbi beslenme tedavisi bireysel olarak düzenlenmeli, oral yolla yeterli enerji ve besin ögesi alamayan hastalar ve beden kütle indeksi $<20 \mathrm{~kg} / \mathrm{m}^{2}, 6$ ayda \%10'dan fazla ağırlık kaybı, serum albümin $<3.5 \mathrm{~g} / \mathrm{dL}$ ve serum prealbümin $<30 \mathrm{mg} / \mathrm{dL}$ gibi düşük nütrisyonel parametreleriyle belirlenen beslenme yetersizliği olan hastalar için mutlak beslenme desteği verilmelidir. Hastalar hastalığına özel diyet ve/veya oral nütrisyonel destek ile günlük beslenme gereksinmesini karşılayamadığında önce tüple enteral beslenme önerilir. Enteral beslenme uygulanamıyor ise total parenteral beslenme veya hemodiyaliz anında intradiyalitik parenteral beslenme uygulanmalıdır. Bu derleme makalede, böbrek hastalıklarında beslenme destek tedavi yöntemlerine odaklanılacaktır.

Anahtar kelimeler: Böbrek hastalıkları, enteral beslenme, parenteral beslenme

\section{ABSTRACT}

Chronic kidney disease (CKF) is a state of permanent decrease in glomerular filtration rate (GFH) that will cause established changes in kidney functions. End stage renal disease (ESRD) is characterized with irreversible loss of renal functions, and this constitutes a clinical state that requires renal replacement treatments such as dialysis and transplantation in order to be protected from harmful and life threatening effects of uremia. The incidence and prevalence of ESRD is increasing globally. Uremia decreases appetite and causes reduced food intake that is related with its negative effects on the gastrointestinal system function, metabolic asidosis, uremic toxicity, and induction of protein catabolism. Malnutrition is an important problem in ESRD. Protein energy malnutrition in ESRD is strongly related with increased morbidity and mortality. Since malnutrition is a common problem, periodic assessment of nutritional status should be part of the routine care of dialysis patients to permit early recognition and the institution of appropriate therapy. The first step is the modification of the diet for each individual. Nutritional support is indicated in undernourished ESRD patients as defined by low nutritional indices, mainly body mass index less than $20 \mathrm{~kg} / \mathrm{m}^{2}$, body weight loss more than $10 \%$ over 6 months, serum albumin less than

1. İletişim/Correspondence: Başkent Üniversitesi, Sağllk Bilimleri Fakültesi, Beslenme ve Diyetetik Bölümü, Ankara, Türkiye • E-posta: pfturker@baskent.edu.tr ○ https://orcid.org/0000-0002-4254-3711 
$3.5 \mathrm{~g} / \mathrm{dL}$ and serum prealbumin less than $30 \mathrm{mg} / \mathrm{dL}$ and in cases where normal food intake is inadequate. If the patients can not tolerate oral nutritional support, tube feeding is recommended. If the patients can not tolerate enteral nutrition with tube feeding, then parenteral nutrition or intradialytic parenteral nutrition in hemodialysis patients is offered. In this review article, nutritional support in kidney diseases will be focused.

Keywords: Renal diseases, enteral nutrition, parenteral nutrition

\section{GíRiş}

Böbrekler, vücudun sıvı ve elektrolit dengesinin sağlanmasından, metabolik atıkların (üre, ürik asit ve kreatinin) kandan uzaklaştırılmasından, kan basıncının kontrolünden ve hormon üretiminden sorumludurlar (1). Kronik böbrek yetmezliği (KBY), çeşitlihastalıklarabağlıolarakgelişen kronik, progresif ve geri dönüşümsüz nefron kaybı sonucu gelişen ve glomerül filtrasyon hızının (GFH) azalması sonucu böbreğin sıvı-solüt dengesini ayarlayan ve sıklıkla son dönem böbrek yetmezliğine (SDBY) götüren bir hastalıktır. SDBY'de, endojen böbrek işlevinin geri dönüşümsüz kaybı ile karakterize ve hayatı tehdit eden üremiden korunmak için hastaya devamlı olarak hemodiyaliz, sürekli ayaktan periton diyalizi veya transplantasyon gibi renal replasman tedavileri uygulanır (2). Amerika Birleşik Devletleri'nde Ulusal Böbrek Vakfı Böbrek Hastalığı Sonuçları Kalite Girişimi tarafından (National Kidney FoundationKidney Disease Outcomes Quality Initiative [NKF/ KDOQI]) kronik böbrek hastalığı şiddeti ile ilgili bir kılavuz hazırlanmıştır. Bu kılavuzda kronik böbrek hastalığı şiddeti Tablo 1'de gösterildiği gibi evrelendirilmiştir $(3,4)$.

Tablo 1. Kronik böbrek hastalığı evrelendirmesi $(3,4)$

\begin{tabular}{lll}
\hline Evre & Belirti & $\begin{array}{l}\text { GFH } \\
\left(\mathbf{m L} / \mathbf{d k} / \mathbf{1 . 7 3 2} \mathbf{~ m}^{\mathbf{2}}\right)\end{array}$ \\
\hline 1 & Böbrek hasarı ve normal GFH & $\geq 90$ \\
2 & Böbrek hasarı ve hafif GFH & $60-89$ \\
3 & Orta derece GFH & $30-59$ \\
4 & Ağır derecede GFH & $15-29$ \\
5 & Böbrek yetmezliği & $<15$ (veya diyaliz) \\
\hline
\end{tabular}

GFH: Glomerül filtrasyon hızı

Türk Nefroloji Derneği (TND) tarafından gerçekleştirilen Türkiye Kronik Böbrek Hastalığı prevalans (Chronic Renal Disease in Turkey/ CREDIT) çalışması, Türkiye'de erişkinlerin \%15.7'sinde KBY bulunduğunu göstermiştir (5). TND Böbrek Kaylt Sistemi verilerine göre ülkemizde SDBY'nin prevalansı giderek artmaktadır (6). Türkiye'de 2017 yll SDBY insidansı milyon nüfus başına 146, prevalansı ise 957 olarak saptanmıştır (7).

Geçmişte en önemli KBY nedeni glomerulonefrit olmasına karşılık, günümüzde SDBY’ye neden olan etmenlerin Amerika Birleşik Devletleri Renal Data Sistemi (United States Renal Data System/ USRDS) verilerine göre ilk sirada diabetes mellitus, ikinci olarak hipertansiyon olduğu belirtilmektedir. Kronik glomerülonefritin ise etiyolojide üçüncü sırayı izlediği söylenmektedir (8). Türk Nefroloji Derneği 2017 yılı verilerine göre ise Türkiye'de görülen en önemli etiyolojik etmenler tip 2 diyabet (\%38), hipertansiyon (\%27.5) ve kronik glomerulonefrittir (\%6.0) (7). Bu derleme makalede, böbrek hastalıklarında beslenme destek tedavi yöntemlerine odaklanılacaktır.

\section{Kronik Böbrek Yetmezliğinin Komplikasyonları}

Kronik böbrek yetmezliği, her evresinde kardiyovasküler ölüm, serebrovasküler hastalıkları, periferik arter hastalığı, kemik-mineral bozuklukları, metastatik kalsifikasyonlar, elektrolit bozuklukları riskini arttırır (9) ve ayrica SDBY'de hipertansiyon, hiperlipidemi, anemi, renal osteodistrofi, asidozis, ödem, beslenme bozuklukları olan malnütrisyon gibi komplikasyonlar gelişmeye başlar (10).

Protein enerji malnütrisyonu varlığı SDBY'de artmış mortalite ve morbidite ile ilişkilidir $(11,12)$. NKF/KDOQI rehberlerine göre, SDBY olan hastaların nütrisyonel değerlendirilmesinde klinik 
değerlendirme ve biyokimyasal testlerin beraber yorumlanmasının en doğru sonuca ulaştıracağı ve düzenli diyaliz tedavisi gören hastalarda beslenme durumunun değerlendirilmesinin tek bir ölçümden ziyade geçerliliği kanıtlanmış ve birbirini tamamlayan ölçümlerin kombinasyonu sonucu yapılması gerektiği belirtilmiştir (13). Malnütrisyon birçok etmenin değişik derecelerde katkıda bulunduğu bir bulgu olduğu için son dönem böbrek yetmezliği olan SAPD veya HD'ye giren hastalarda protein enerji malnütrisyonunu en hatasız şekilde hangi yöntemin gösterebileceğini bulmak için araştırmalar yapılmış, bunların sonucunda basit ya da karmaşı birçok yöntem geliştirilmiştir (14-16).

Hastalara uygulanan iyi düzenlenmiş bir beslenme programı, böbrek yetmezliğinde rasyonel tedavinin en başta gelen kısmıdır. Böbrek hastalarında semptomların azaltılması ve ilerlemesinin önlenmesi bakımından diyet uygulamaları gereklidir. Böbrek hastalıklarında nütrisyon tedavisi, akut böbrek hasarı olan ve renal replasman tedavisi alan hastalarda olmak üzere iki şekilde uygulanmaktadır (17).

\section{Akut Böbrek Hasarı}

Akut böbrek hasarı (ABH) hastanede yatan hastalarda sık karşılaşılan bir komplikasyondur. Akut böbrek hasarlı hastalarda malnütrisyon, komplikasyon gelişme riski, hastane mortalitesinde artış ile ilişkilidir. Bu nedenle ABH'lı hastaların tedavisinde uygun beslenme desteğinin yer alması gereklidir. Akut böbrek hasarında beslenme gereksinmesi değerlendirilirken hastanın altta yatan hastalığı, komorbid durumları ve böbrek işlev bozukluğunun ciddiyeti ile renal replasman tedavisi (RRT) gereksinmesi dikkate alınmalıdır. ABH'de beslenme desteğinde nütrisyonel gereksinmeler, normal böbrek işlevine sahip kritik hastalar için önerilen gereksinimlere benzerdir. Yeterli enerji ve besin ögelerini sağlayarak nütrisyonu sürdürmek ya da iyileştirmek, metabolik komplikasyonlara eşlik eden protein-enerji alımını önlemek, sıvı elektrolit dengesini korumak, yara iyileşmesini hızlandırmak ve immün sistemi desteklemektir (18).

$\mathrm{Bu}$ hastalarda enerji gereksinmesi ABH'nin altında yatan nedenlere, hastalıklara ve ilişkili komplikasyonlara göre belirlenir. Aşırı enerji alımı aşırı CO2 üretimine neden olup solunumu azaltır. Normalde ABH'de enerji gereksinmesi 25-30 kkal/ kg/gün iken hiperkatabolizmada, sepsisin varlığında ya da multi-organ disfonksiyon sendromu (MODS) geliştiğinde bu gereksinme 35 kkal/kg/gün'e kadar arttırllabilir (19).

Pozitif nitrojen dengesi için protein gereksinmesi katabolik orana, böbrek işlevine ve diyaliz tipleriyle oluşan protein kayıplarına göre ayarlanmalıdır. Hasta nonkatabolik, stabil durumda ise en düşük olası protein gereksinmesi 0.8-1.0 g/kg/gün, GFH normale döndükçe ise protein gereksinmesi arttırılmalı ve hiperkatabolizma durumunda ve diyalize giren $\mathrm{ABH}$ olan hastalarda ise günlük 1.2-1.5 $\mathrm{g} / \mathrm{kg}$ protein önerilmektedir (20).

ABH'de beslenme desteği endikasyonları diğer kritik hastalığı olan bireylerdekinden farklı değildir (18). Kritik hastalara benzer şekilde beslenme desteğini sağlama yolu ABH'nin varlığından çok gastrointestinal (GI) işlevlere bağlıdır. Gastrointestinal sistem işlevsel ise enteral beslenme uygulanmalıdır. Komplike olmayan ABH'de normal beslenme ve oral nütrisyonel destek gereksinmeleri karşılamaya yetmiyor ise tüple beslenme uygulanmalıdır. Akut böbrek yetmezliğinde tüple enteral beslenme için öneriler yoğun bakım ünitesi hastalarıyla aynıdır. Mümkünse 24 saat içinde enteral beslenmeye geçilmelidir $(19,20)$.

Gastrointestinal sistem çalışmıyorsa ve enteral beslenme ile istenilen hedef doza ulaşılamadığında kısa bir zaman dilimi için ( $<7$ gün) ABH’li hastalarda periferik parenteral beslenme kullanılabilir. Sıvı kısıtlama gereksinmesi ve daha yoğun yüksek osmolariteli hazır ürünler kullanılması nedeniyle özellikle yoğun bakım ünitesindeki ABH'li hastalarda parenteral beslenme için santral ven kullanılmalıdır (21). 


\section{Renal Replasman Tedavisi Olan Hastalarda Nütrisyon Desteği}

Hastalığın başlangıcında ilaç ve diyet tedavisi yeterli olsa da üremik belirti ve bulguların kontrol edilemediği en son evrede hastalığın kötü gidişini durdurmak veya azaltmak, yaşamlarını sürdürebilmek için diyet tedavisine ek olarak hastalara renal replasman tedavisi yapılmaktadır. Renal replasman tedavileri diyaliz (hemodiyaliz, sürekli ayaktan periton diyalizi) veya böbrek transplantasyonudur (22).

Kronik böbrek yetmezliği olan hastaların tıbbi beslenme tedavisi önerileri farklılık göstermesiyle birlikte en yaygın kullanılan beslenme kılavuzları, Amerika Birleşik Devletleri'nde Ulusal Böbrek
Vakfı'nın Böbrek Hastalığı Sonuçları Kalite Girişimi (NKF/KDOQI / National Kidney Foundation Kidney Disease Outcomes Quality Initiative) , Avrupa Parenteral ve Enteral Nütrisyon Derneği ( European Society for Parenteral and Enteral Nutrition / ESPEN) ve Avrupa Böbrek Birliği/Avrupa Diyaliz ve Transplantasyon Birliği’nin Avrupa En İyi Uygulama Kılavuzları (European Renal Association/European Dialysis and Transplant Association-European Best Practice Guidelines /ERA/EDTA Council EBPG Guideline) önerileridir. ESPEN nütrisyon rehberine göre stabil kronik böbrek yetmezliği ve renal replasman tedavisinde olan hastalarda besin ögesi gereksinmeleri Tablo 2'de özetlenmiştir (23).

Tablo 2. KBY ve renal replasman tedavisi (HD-SAPD) alan hastalarda günlük enerji ve besin ögesi gereksinmeleri (23)

\begin{tabular}{llll}
\hline Enerji ve besin ögeleri & KBY & HD & SAPD \\
\hline Enerji (kkal/kg) & $>35$ & $\geq 35(>\% 50 \mathrm{HBV})$ & $\geq 35(>\% 50 \mathrm{HBV})$ \\
Protein (g/kg) & $0.6-1.0$ & $1.2-1.4$ & $1.2-1.5$ \\
Fosfor (mg) & $600-1000$ & $800-1000$ & $800-1000$ \\
Potasyum (mg) & $1500-2000$ & $2000-2500$ & $2000-2500$ \\
Sodyum (g) & $1.8-2.5$ & $1.8-2.5$ & $1.8-2.5$ \\
Sivi (mL) & Kisitlama yok & $1000+$ idrar hacmi & $1000+$ idrar hacmi \\
\hline
\end{tabular}

KBY: Kronik böbrek yetmezliği, HD: Hemodiyaliz, SAPD: Sürekli ayaktan periton diyalizi, HBV: Yüksek biyolojik değer

NKF/DOQI önerilerine göre, enerji gereksinmesi renal replasman tedavisi alan 60 yaş altında olan hastalarda 35 kkal/kg/gün (ideal vücut ağırlığı başına), 60 yaş üzerinde olanlarda ise $30-35 \mathrm{kkal} / \mathrm{kg} /$ gün (ideal vücut ağırlığı başına) önerilmektedir. Hasta obez ise 25-30 kkal/kg/gün, PEM varsa >35 kkal/kg/gün olarak verilmektedir. Bu grup hastalarda protein gereksinmesi prediyaliz döneminde 0.6-0.75 g/kg/gün, hemodiyalizde $1.2 \mathrm{~g} / \mathrm{kg} / \mathrm{gün}$, periton diyalizinde 1.21.3-1.5 g/kg/gün (\%50’si yüksek biyolojik değerlikli) olmalıdır (24,25). ERA/EDTA'nın EBPG önerilerine göre hemodiyaliz hastalarının enerji ve protein gereksinmelerini önerilen miktarlarda karşllayarak BKİ $>23 \mathrm{~kg} / \mathrm{m}^{2}$ olacak şekilde sağlanmalıdır (Kanıt düzeyi III) (26).

Renal replasman tedavisi alan SDBY hastalarında kötü beslenme nedeniyle alım yetersizliği, üremi nedeniyle oluşan metabolik bozukluklar, ilaçlar tarafindan gastrointestinal emiliminin engellenmesi, enfeksiyon, gastrointestinal hastalıklar gibi eşlik eden diğer hastalıklar veya komplikasyonlar, SAPD'de diyalizat yolu ile ve hemodiyaliz sırasında oluşan kayıplar vitamin, mineral yetersizliğine yol açmaktadır. Hastaların vitamin gereksinmeleri yaş, cinsiyet, vitamin alım düzeyleri, rezidüel böbrek işlevi, diyaliz süresi, diyalizat tipi, metabolizmaya bağlı yani bireyseldir. ERA/EDTA'nın EBPG önerilerine göre özellikle suda çözünen vitaminlerin ya günlük ya da diyaliz sonrası haftada $3 \mathrm{kez}$ verilmesi önerilmektedir (26).

$\mathrm{Bu}$ hastalarda beslenme desteğinin hedefleri, böbrek bozukluğunun şiddetine, malnütrisyonun derecesine ve komorbid durumuna bağlıdır. Bu hastalarda besin alımının arttırılmasında, nütrisyonel danışmanlıkla hastanın diyaliz dönemine uygun protein, enerji ve besin ögelerini sağlayacak diyetinin düzenlenmesi 
veya arttırılması, oral nütrisyonel suplement (ONS), enteral beslenme (nazogastrik beslenme, perkütan endoskopik gastrostomi vb.), parenteral beslenme ve intradiyalitik parenteral beslenme gibi yöntemler uygulanabilmektedir (27).

\section{Oral Nütrisyonel Destek}

Nütrisyon yetersizliği olan kronik böbrek yetmezliği olan hastalarda oral nütrisyon ürünleri verilebilir. Besin alımını iyileştirmek amacıyla ONS, ESPEN tarafindan önerilmektedir (Düzey A) (20). ONS ile enteral beslenme ise konvansiyonel olarak tedavi edilmiş kronik böbrek yetmezliği olanlarda ve diyaliz hastalarında tercih edilmektedir. Yapılan bir çalışmada ONS’nin nütrisyonel parametreler üzerinde pozitif etkileri olduğu bildirilmiştir (23). ONS ana öğünlerden 2-3 saat sonra ya da hemodiyaliz seansı sirasinda verilmelidir (28).

\section{Enteral Beslenme}

Hastalarda spontan protein ve enerji alımları sırasıyla $<0.8 \mathrm{~g} / \mathrm{kg} /$ gün protein ve $<20 \mathrm{kkal} / \mathrm{kg} / \mathrm{gün}$ ve/veya stres durumlarında, katabolik durum nedeniyle oral beslenmenin mümkün olmadığı zaman veya hastanın şuuru kapalı, ayrıca gastrointestinal sistem işlevsel ise enteral beslenme (EN) önerilmelidir (23,29). EN, beslenme desteğinin temelini oluşturmaktadır. Enteral beslenme desteğinin verilmesi özellikle akut böbrek yetmezliği olan hastaların tedavisi için uygun bir yöntemdir. SDBY olan hastalarda enteral beslenme, böbreği iskemik yaralanmalardan korumakta ve daha iyi intravasküler hacim sağlayarak kardiyak çıtıyı desteklemektedir. Bununla birlikte, enteral beslenme en ekonomik yöntem olmanın yanı sira, en fizyolojik yoldur ve EN, parenteral beslenmeye göre tercih edilmelidir $(23,28)$. Nütrisyon danışmanına ve ONS’ye rağmen uygun oral alımın mümkün olmadiğı durumlarda enteral beslenme desteği nazogastrik tüple veya perkütan endoskopik gastrostomi (PEG) yoluyla yapılmalıdır (Kanıt düzeyi IV). Özellikle diyabetik nefropatili hastalarda meydana gelen ve prokinetik tedaviye yanıtsız gastroparezik hastalarda nazojejunal tüple beslenme tercih edilmelidir. Sürekli ayaktan periton diyaliz uygulanan erişkin hastalarda ise, peritonit insidansındaki artışa bağlı olarak, PEG ya da perkütan endoskopik jejunostomi (PEJ) kontreendikedir $(23,26)$. ESPEN kılavuzlarına göre, beslenme yetersizliği olan SDBY hastalarında kısa süreli enteral beslenme için standart formüller kullanılmalıdır ancak 5 günü aşan EN için elektrolit içeriği azaltılmış düşük proteinli hastalığa özgü polimerik böbrek hastalığına özgü ürünler kullanılmalıdır. Tüple beslenmede ise HD hastalarına özgü orta düzeyde protein içeren, elektrolit miktarı (potasyum, fosfor) azaltılmış enteral ürünler tercih edilmelidir. Sürekli ayaktan periton diyalizi (SAPD) hastaları içinse yüksek protein ama düşük karbonhidrat içerikli enteral formüller tercih edilmelidir (23).

\section{Total Parenteral Beslenme}

Kılavuza göre, hastalarda yoğun diyet desteği, oral destekler ve enteral beslenme ile önerilen hedef doza ulaşllamadığında, gastrointestinal sistem çalışmadığında parenteral beslenme önerilir. Parenteral beslenmede hastalara uygulanacak beslenme destek süresi 7 günden fazla ise santral venöz ile parenteral beslenme, 7 günden az uygulanacaksa, sıvı kısıtlama gereksinmesi ve enerji/ protein hedefine uygun olarak periferik parenteral beslenme önerilmelidir. Sıvı kısıtlaması gerekliliği nedeniyle özellikle yoğun bakımdaki böbrek hastalarına santral yolla infüzyon gerekmektedir (Düzey C) (26,30). Malnütrisyon tanısı konulmuş hemodiyalize giren SDBY hastalarında parenteral beslenme endikedir. Ayaktan hemodiyaliz tedavisi gören hastalarda ise, nütrisyonel danışmanlık ve ONS başarısızsa intradiyalitik parenteral beslenme (IDPN) önerilmelidir (30). Ayrıca, SAPD tedavisi gören SDBY hastalarinda parenteral beslenmeye yalnızca malnütrisyonlu ve stres altındaki veya peritonit tanısı almış, nütrisyonel gereksinmeleri oral veya enteral yolla sağlanamadığında başvurulmalıdır (Düzey C). SDBY olan hastalar için tüm elzem ve elzem olmayan aminoasit içeren standart parenteral solüsyonlar ya da elektrolit bozukluğu olan renal 
yetmezlikli hastalar için hazırlanan özel içeriğe sahip parenteral böbrek hastalığına özgü solüsyonları kullanılması avantajlıdır. Hastalara total parenteral beslenmede vitamin ve eser elementler intravenöz yolla verilmelidir. Gastrointestinal işlevler normale döndüğünde parenteral beslenme kademeli olarak giderek azaltılmalı, enteral nütrisyona mümkünse oral beslenmeye geçilmelidir (20).

\section{Intradiyalitik Parenteral Beslenme}

Hemodiyaliz uygulaması yeterli olan (Diyaliz yeterliliği $=\mathrm{Kt} / \mathrm{V} \geq 1.2$ ve Ürenin Azalma Hızı= URR $>\% 65), 3$ ay boyunca günlük besin ögesi gereksinmesini diyet ve ek besinlerle karşllayamayan, enteral tüple beslenmeye uygun olmayan, malnütrisyonu olan hastalarda ve/veya hastada besin alımını ve beslenme durumunu düzeltecek alternatif stratejilerde başarısız olunduysa hemodiyaliz anında intradiyalitik parenteral beslenme (IDPN) uygulanabilmektedir (30). Genelde ONS ve IDPN sadece $5-10 \mathrm{kkal} / \mathrm{kg} / \mathrm{gün}$ ve 0.2-0.6 $\mathrm{g} / \mathrm{kg} / \mathrm{gün}$ protein sağlamaktadır (31). Bu nedenle, kllavuza göre IDPN, spontan enerji alımı >20 $\mathrm{kkal} / \mathrm{kg} /$ gün (ideal vücut ağırlığı başına) ve protein alımı >0.8 g/k/gün (ideal vücut ağırlığı başına) olan malnütrisyonu olan bireylerde önerilir (26). Protein ve enerji alımları spontan alımlardan daha düşük olduğunda enteral beslenme, enteral beslenmenin yapılamadığı durumlarda tüm gün total parenteral beslenme yapılmalıdır $(26,32)$.

IDPN başlama kriterleri yani endikasyonları, üç ay prediyaliz serum albümini <3.4 g/dL, üç ay prediyaliz serum kreatinin < $8 \mathrm{mg} / \mathrm{dL}$, ideal vücut ağırlı̆̆ının $>\% 10$ kaybı, orta-ciddi malnütrisyon varlığı, diyetle azalmış alım hikayesi ( $<0.8 \mathrm{~g} / \mathrm{kg}$ protein, $<25 \mathrm{kkal} / \mathrm{kg}$ enerji), subjektif global değerlendirmeye göre ciddi malnütrisyon varlığıdır. Bu kriterlerden herhangi üçünün varlığıyla birlikte diyet ve oral desteğin arttırılmasına yönelik girişimlerin yetersizliği, enteral tüp ile beslenmenin reddedilmesi durumunda IDPN önerilebilir. IDPN sonlandırma kriterleri ise, üç ay süreyle serum albümini $>3.8 \mathrm{~g} / \mathrm{dL}$, üç ay süreyle serum kreatinin $>10 \mathrm{mg} / \mathrm{dL}$, düzelmiş beslenme klinik bulguları, subjektif global değerlendirmede
A veya $\mathrm{B}$, artmış oral alım (>1 g/kg protein, $>30 \mathrm{kkal} /$ $\mathrm{kg}$ enerji) olarak belirtilmektedir. Bu kriterlerden herhangi üçünün varlığı veya 6 aylık IDPN tedavisine rağmen düzelme olmaması, IDPN tedavisine komplikasyonlar nedeniyle intolerans gelişmesi IDPN'nin sonlandırılmasını gerektirir (33).

IDPN solüsyonu hastalara \%10-15'lik aminoasit 500 mL, \%50-70'lik dekstroz 250 mL, \%10-20’lik lipit emülsiyonu $250 \mathrm{~mL}$ olarak verilebilir. Bu solüsyonlar diyaliz seansı başına 650-1100 kkal enerji, 50-90 $\mathrm{g}$ protein içeren beslenme desteği sağlamaktadır. Hastaya IDPN solüsyonu diyaliz seansı boyunca periferik venden parenteral destek sağlanarak venöz kan setinden yavaş olarak verilmelidir (33). IDPN ile yapılan çalışmalarda, hastaların hastanede kalış süresinin azaldığı, yaşam kalite düzeylerinin arttığı, ölüm riskinin azaldığı bildirilmiştir $(34,35)$.

\section{SONUÇ VE ÖNERILER}

Sonuç olarak, SDBY olan hastalara öncelikle bireysel tıbbi beslenme tedavisi uygulanmall ve hastalar izlenmelidir. Oral yolla yeterli enerji ve besin ögesi alamayan hastalar için mutlak beslenme desteği verilmelidir. Hastalar, diyet, ONS ve IDPN kombinasyonu ile günlük beslenme gereksinmesini karşılayamadığında ise önce enteral beslenme, enteral beslenme uygulanamıyorsa total parenteral beslenme uygulanmalıdır (31).

Çıkar çatışması - Conflict of interest: Yazarlar çıkar çatışması olmadığın beyan ederler. - The authors declare that they have no conflict of interest.

\section{KAYNAKLAR}

1. Widmaier E.P, Raff H, Strang KT. Böbrekler, su ve inorganik iyonların düzenlenmesi. Demirgören $S$, editör. Vander İnsan Fizyolojisi. 10. Baskı. İzmir: Güven Kitabevi; 2010.s.490-532.

2. Tanrıverdi MH, Karadağ A, Hatipoğlu EŞ. Kronik böbrek yetmezliği. Konuralp Tip Dergisi 2010;2(2):27-32.

3. Levey AS, Eckardt KU. Definition and classification of chronic kidney disease. A position statement from Kidney Disease: Improving Global Outcomes. Kidney Int 2005;67:2089-100. 
4. National Kidney Foundation-K/DOQI Clinical practice guidelines for chronic kidney disease, evalution classification and stratification. Am J Kidney Dis 2007;49(2)(suppl 2):S13-S19.

5. Süleymanlar G, Utaş C, Arınsoy T, Ateş K, Altun B, Altiparmak MR, et al. A population based survey of chronic renal disease in Turkey - The CREDIT study. Nephrol Dial Transplant 2011;26:1862-71.

6. Plantinga LC, Boulware LE, Coresh J, Stevens LA, Miller ER, Saran R, et al. Patient awareness of chronic kidney disease: Trends and Predictors. Arch Intern Med 2008;168:2268-75.

7. Süleymanlar G, Ateş K, Siyahi N. T.C. Sağlık Bakanlığı ve Türk Nefroloji Derneği Ortak Raporu. Türkiye'de Nefroloji, Diyaliz ve Transplantasyon 2017 Raporu. Ankara: Türk Nefroloji Derneği Yayınları; 2018.s.1-140.

8. Yeniçerioğlu Y. Kronik böbrek hastalığı epidemiyolojisi. Türkiye Klinikleri J Nephrol 2008;1(2):1-5.

9. KDIGO 2012 Clinical practice guideline for the evaluation and management of chronic kidney disease. Kidney Int Suppl 2013;3:1-150.

10. Wilkens Kg, Juneja V, Shanaman E. Medical nutrition therapy for renal disorders. In: Mahan LK, Escott-Stump S, Raymond J, editors. Krause's Food and Nutrition Care Process. 13th ed. USA: Saunders Elsevier; 2012. p.799831.

11. Sezer S, AratZ, Özdemir FN. Kronik böbrekyetmezliğinde malnutrisyon. Türk Nefroloji ve Transplantasyon Dergisi 2000;3:125-29.

12. Caimi G, Carollo C, Presti R. Pathophysiological and clinical aspects of malnutrition in chronic renal failure. Nutr Res Rev 2001;21:343-79.

13. Kopple JD. Rationale for an International Federation of Kidney Foundations. Am J Kidney Dis 2000;36:1059-70.

14. Pupim LB, İkizler A. Assessment and monitoring of uremic malnutrition. J Ren Nutr 2004;14:6-9.

15. Locatelli F, Fouque D, Heimburger O, Drüeke TB, Canata-Andia JB, Hörl W, et al. Nutritional status in dialysis patients: A European Concensus. Nephrol Dial Transplant 2002;17:563-72.

16. Kopple JD. Rationale for an International Federation of Kidney Foundations. Am J Kidney Dis 2000;36:1059-70.

17. Mehrotra R, Kopple JD. Nutritional management of maintance dialysis patients. Why aren't we going better? Annu Rev Nutr 2001;21:343-79.

18. Bilgiç A, Akçay A, Sezer S. Akut böbrek hasarında beslenme desteği. Turk Neph Dial Transpl 2013;22(1):715.

19. Brown RO, Compher C. A.S.P.E.N. Clinical Guidelines: Nutrition support in adult acute and chronic renal failure. J Parenter Enteral Nutr 2010;34 (4):366-77.

20. Cano NJ, Aparicio M, Brunori G, Carrero JJ, Cianciaruso B,Fiaccadori E, et al. ESPEN guidelines on parenteral nutrition: Adult renal failure. Clin Nutr 2009;28(4):40114.

21. Brown RO, Morgan LM, Bhattacharya SK, Johnson PL, Minard G, Dickerson RN. Potential aluminum exposure from parenteral nutrition in patients with acute kidney injury. Ann Pharmacother 2008;42(10):1410-15.

22. Blumenkrantz MJ. Beslenme. Bozfakıoğlu S, Ecder T, editör. Diyaliz El Kitabı. 2.baskı. İstanbul: Nobel Tip Kitabevi;1997. s.374-99.

23. Cano N, Fiaccadori E, Tesinsky P, Toigo G. ESPEN guidelines on enteral nutrition: Adult renal failure. Clin Nutr 2006;25:295-310.

24. Kopple JD. K/DOQI clinical practice guidelines for nutrition for chronic dialysis patients. Am J Kidney Dis 2001;37(1):S66-S70.

25. Eknoyan G, Levin N. K/DOQI clinical practice guidelines for nutrition in chronic renal failure. Am J Kidney Dis 2000;35(6)(Suppl 2):S17-S104.

26. Fouque D, Vennegoor M, Ter Wee P, Wanner C, Baser A. EBPG guideline on nutrition. Nephrol Dial Transplant 2007;22(Suppl 2):ii45-ii87.

27. Rocco MV, Paranondi L, Burrowes JD. Nutritional status in the HEMO study cohort at baseline (HD). Am J Kidney Dis 2002;39:245-56.

28. Akpınar H. Renal hastalıkta nütrisyonel destek. Haldun Gündoğdu, editör. Klinik Nütrisyonun Temelleri. 4. Baskı. Ankara: Bayt Bilimsel Araştırmalar Basın Yayın; 2013. s:473-84.

29. Toigo G, Aparicio M, Atman PO. Expert working group report on nutrition in adult patients with renal insufficiency. Clin Nutr 2000;19:281-91.

30. Mc Cann L, Feldman C, Hornberger J, Belanger S. Effect of intradialytic parenteral nutrition on delivered Kt/V. Am J Kidney Dis 1999;33:1131-35.

31. Cano N, Leverve MX. Intradialytic nutritional support. Curr Opin Clin Nutr Metab Care 2008;11:147-51.

32. Cano N. Nutritional supplementation in adult patients on hemodialysis. J Ren Nutr 2007;17:103-5.

33. Serna-Thome MG, Padilla-Rosciano AE, Suchil-Bernal L. Practical aspects of intradialytic nutritional support. Curr Opin Clin Nutr Metab Care 2002;5:293-96.

34. Foulks CJ. The effect of intradialytic parenteral nutrition on hospitalization rate and mortality in malnourished hemodialysis patient. J Renal Nutr 1994;4:5-10.

35. Cranford W. Cost-effectiveness of IDPN therapy measured by hospitalizations and length of stay. Nephrol News Issues1998;12:33-39. 